\title{
PENTINGNYA PENDIDIKAN KARAKTER TERHADAP PESERTA DIDIK YANG KECANDUAN GAME ONLINE
}

\author{
Agustina Hayati \\ Universitas Lambung Mangkurat \\ 1910128120007@mhs.ulm.ac.id
}

\begin{abstract}
:
Nowadays, advances in technology and information are felt in all circles of society. One of them is the rapid development of online games favored by students. It is not uncommon for students to love online games to cause addiction. The purpose of this writing is as a conscious way or effort to apply character education to the many cases of students addicted to online games. Character education is an education which includes several aspects of abilities that can be assessed including affective abilities, cognitive abilities, and psychomotor abilities. In this aspect of ability, educators have a responsibility towards students. The existence of character education is expected to be able to make students better in carrying out the survival of the nation and state.
\end{abstract}

Keywords: Character education, online games, online game influence

\begin{abstract}
Abstrak:
Dizaman sekarang kemajuan teknologi dan informasi sangat terasa disemua kalangan masyarakat. Satu diantaranya berkembang pesatnya game online yang digemari oleh peserta didik. tidak jarang kegemaran yang dilakukan peseta didik terhadap game online menyebabkan kecanduan. Tujuan dari penulisan ini adalah sebagai cara atau usaha sadar dengan menerapkan pendidikan karakter terhadap banyaknya kasus peserta didik kecanduan game online. Pendidikan karakter merupakan suatu pendidikan yang didalam nya mencakup beberapa aspek kemampuan yang dapat di nilai diantaranya adalah kemampuan afektif, kemampuan kognitif, dan kemampuan psikomotorik. Dalam aspek kemampuan tersebut tenaga pendidik memiliki tanggung jawab terhadap peserta didik. Adanya pendidikan karakter diharapkan dapat menjadikan peserta didik yang untuk lebih baik dalam menjalankan kelangsungan hidup yang berbangsa dan bernegara.
\end{abstract}


Kata kunci: Pendidikan karakter, game online, pengaruh game online

\section{PENDAHULUAN}

Adanya sekolah sebagai lembaga pendidikan yang merupakan sebuah wadah yang sangat tepat untuk mewujudkan tujuan dari pendidikan, yaitu dengan menciptakan peserta didik agar memiliki suatu prestasi yang terbaik, didapatkan saat proses belajar di sekolah berlangsung dan agar memiliki bekal kemampuan serta keterampilan untuk kehidupan dimasa yang mendatang. Pendidikan karakter merupakan bagian dari sistem atau proses pendidikan yang bertujuan sebagai pembentukan kepribadian peserta didik. Dengan ada nya pendidikan karakter, terdapat cara untuk melakukan pendidikan karakter dengan sadar dan terencana agar dapat melakukan pengembangan terhadap karakter yang baik terhadap pribadi peserta didik, yang berpedoman pada kebajikan-kebajikan secara nyata terhadap individu atau peserta didik dan masyarakat. Dalam hal membentuk sutau kepribadian individu pada pendidikan yang dapat mencakup diantaranya adalah sifat, sikap, reaksi, perbuatan atau perilaku.

Pendidikan karakter memiliki arti sebagai sebuah pendidikan dalam pembelajaran yang berupa budi pekerti plus, yang artinya mengaitkan beberapa aspek diantaranya adalah aspek pengetahuan (cognitive), perasaan (feeling), dan tindakan (action) (Suyanto, 2009: 1). Mengenai penerapan pendidikan karakter tersebut dapat melalui media apa saja yang tgerdapat disekitar peserta didik. Media tersebut seperti, keluarga, lembaga pendidikan, lingkungan masyarakat, sistem pemerintahan, kawasan usaha, serta media massa (Kemdiknas, 2011). Berdasarkan Kamus Besar Bahasa Indonesia (2008: 623) bahwa karakter bermakna sifat kejiwaan, akhlak atau pun budi pekerti membedakan individu dengan lainnya, tabiat, dan watak.

Dalam penerapan pendidikan karakter pada dunia pendidikan memiliki fungsi nya tersendiri, yaitu yang berfungsi sebagai: (1) menciptakan kehidupan yang berbangsa secara beragam kebudayaan (multikultral). (2) menciptakan kebudayaan berbangsa yang cerdas, berbudaya yang luhur, dan mampu ikut serta dalam mengembangkan kehidupan umat manusia, mengembangkan terhadap potensi dasar supaya dapat berhati baik, memiliki pikiran baik, dan berperilaku dengan baik serta mempunyai keteladanan yang baik. (3) menciptakan sikap atau 
perilaku warganegara yang kreatif, mandiri, cinta damai, dan dapat mampu hidup secara berdampingan bersama bangsa dan Negara lain dalam suatu keharusan yaitu harmoni berbangsa.

Berkembang pesatnya teknologi dan informasi dimasa sekarang ini tidak dapat dipungkiri lagi pengaruhnya terhadap dunia pendidikan. Yang mana hal ini berjalan berdampingan dengan kemajuan didunia pendidikan. Dengan ada nya kemajuan teknologi ini semua hal yang terdapat pada pendidikan akan mengalami kemudahan dari pada sebelum ada nya teknologi. teknologi berperan besar didunia pendidikan, dan banyak membawa pengaruh baik jika tidak disalah gunakan. Adanya internet dan kemajuan teknologi dengan timbulnya media digital yang mengalami pergeseran yang berlangsung didalam kajian pembelajaran yang beralih ke arah yang aktual. Tenaga pendidik diharapkan dan diharuskan agar dapat mengikuti perkembangan zaman dan dapat beradaptasi agar dapat memanfaatkan kemajuan teknologi dan sumber-sumber pembelajaran yang berdasarkan multi-media dengan baik dan benar. Sedari dulu teknologi dan pendidikan merupakan suatu hal yang saling berkesinambungan. Teknologi dalam dunia pendidikan menghasilkan suatu hal yang dapat dimanfaatkan, seperti ada nya ditemukan kertas, mesin cetak, radio, film, TV, komputer dan lain sebagainya. Adanya alat-alat tersebut di dunia pendidikan, tidak dibuat secara khusus untuk kebutuhan pendidikan. Melainkan, manfaat yang terdapat pada masing-masing alat tersebut memiliki nilai guna terhadap dunia pendidikan.

Menurut (B. Uno, 2010) menyatakan bahwa kebiasaan atau rutinitas baru dari dunia edukasi yang ada di Indonesia pada masa yang akan datang, diantaranya adalah sebagai berikut:

1. meruaknya pendidikan yang terbuka dengan berdalih melakukan pembelajaran dengan jarak jauh (distance learing). Selanjutnya, agar dapat terlaksana nya penyelenggaraan pendidikan terbuka dan jarak jauh dapat dimasukkan ke dalam strategi utama.

2. Sharing resource bersama dengan antar lembaga pendidikan/latihan yang terdapat dalam suatu jaringan perpustakaan dan instrument pendidikan lainnya (guru, laboratorium) kemudian mengalami perubahan fungsi yaitu menjadi sumber informasi dari pada sekedar rak buku.

3. Menggunakan suatu perangkat teknologi informasi interaktif, seperti CD-ROM multi media pada dunia pendidikan yang secara bertahap menggantikan televisi dan video.

\section{METODE}


Artikel ini dibuat dengan analisis yang disusun melalui analisis tinjauan pustaka dan diperoleh melalui sumber-sumber yang relevan. Menurut (Rahmah dkk, 2021) Tinjauan pustaka merupakan pengumpulan data perpustakaan dengan objek kajian yang digali yang didasarkan dengan infromasi perpustakaan (buku/ digital). Dalam sumber-sumber yang relevan dapat dikaji dengan menggunakan analisis yang didapatkan pada google scholar.

\section{PEMBAHASAN}

A. Pendidikan karakter

1. Pengertian Pendidikan Karakter

Pendidikan karakter yang terdapat dalam kurikulum 2013 bertujuan untuk meningkatkan mutu proses dan hasil peningkatkan terhadap pendidikan, yang mengarah pada pembentukan budi pekerti dan akhlak mulia peserta didik secara utuh, terpadu, dan seimbang, sesuai dengan standar kompetensi lulusan setiap satuan pendidikan (Mutiani, Syaharuddin (2020: 5)

Pendidikan pada hakikatnya memiliki tujuan dalam penerapannya, yaitu sebagai usaha sadar untuk mencerdaskan kehidupan berbangsa. Pernyataan tersebut sebanding dengan Undang-undang No 20 Tahunn 2003 Pasal 3 mengenai Pendidikan Nasional yang menyatakan bahwa "Pendidikan nasional memiliki fungsi dalam mengembangkan kemampuan dan dalam pembentukan karakter serta dalam peradaban bangsa yang bermartabat dalam rangka mencerdaskan kehidupan berbangsa dan yang bertujuan sebagai cara dalam mengembangkan potensi yang terdapat pada peserta didik, agar menjadi manusia yang beriman, dan berakwa kepada Tuhan Yang Maha Esa, berakhlak mulia, sehat, berilmu, cakap, kreatif, mandiri dan menjadikan warga Negara yang demokratis serta memiliki rasa bertanggung jawab"(Kemendiknas).

Menurut Samani \& Hariyanto (2011: 44) pendidikan karakter merupakan suatu proses untuk memberikan tuntunan kepada peserta didik agar menjadi manusia yang berkarakter seutuhnya, yang mana karakter tersebut terdapat pada dimensi hati, pikir, raga, dan rasa serta karsa. Pendidikan karakter juga dapat dimaknai sebagai sebuah pendidikan berbasis nilai, pendidikan budi pekerti, pendidikan moral, dan pendidikan watak. yang mana hal tersebut memiliki tujuan, yaitu untuk mengembangkan kemampuan 
pada peserta didik agar dapat mengambil keputusan dengan baik tanpa terkecuali, sehingga dapat menerapkan hal-hal yang baik dalam kehidupan sehari-hari.

\section{Tujuan Pendidikan Karakter}

Berdasarkan menurut Kemendiknas (2010) peraturan pemerintah 17 tahun 2010 tentang pengelolaan penyelenggaraan pendidikan pada pasal 17 ayat (3), "pendidikan dasar, termasuk sekolah menengah pertama (SMP) memiliki tujuan untuk membangun landasan bagi berkembangnya potensi, peserta didik agar menjadi manusi yang (a) beriman dan bertakwa kepada Tuhan Yang Maha Esa; (b) berakhlak mulia, dan berkepribadian luhur; (c) berilmu, cakap, kritis, kreatif, dan inovatif; (d) sehat, mandiri dan percaya diri; (e) toleransi, peka sosial, demokratis, dan bertanggung jawab”.

Berdasarkan pernyataan pasal diatas tersebut, bahwa pendidikan memiliki tujuan yang saling berkesinambungan dengan pendidikan karakter. Jadi, dapat disimpulkan dengan ada nya pendidikan yang menerapkan nilai-nilai karakter disekolah bertujuan untuk peserta didik mendapatkan pengalaman baru, dan dulu nya menganggap hal-hal yang sebelumnya dianggap tidak baik sampai dengan menjadi hal-hal yang baik.

3. Faktor penyebab yang mempengaruhi pembentukan karakter

Suparno (2015) menerangkan mengenai faktor penyebab yang mempengaruhi pada pembentukan karakter terhadap individu, diantaranya adalah sebagai berikut:

a. Keluarga

Seorang anak pasti mendapatkan ilmu pengetahuan yang pertama kali nya dari runag lingup keluarga. Dalam hal ini anak pun baru pertama kali mengetahui mengenai karakter. Orang tua sangat mengambil peran besar terhadap hal ini, karena orang tua merupakan sumber pertama anak dalam meniru apa saja yang dilakukan dalam setiap hari nya. Pada saat anak berada dalam kandungan ibu nya pun, anak sudah mulai mempelajari sikap yang ada pada kedua orang tua nya, terutama oleh ibu yang mengandungnya. Tidak hanya itu saja, suasana dalam berkeluarga pun harus harmonis agar tercipta nya perkembangan karakter pada anak dengan baik.

b. Guru

Guruatau tenaga pendidik memiliki peran yang sangat besar terhadap pembentukan pada pendidikan karakter anak. Pendidikan karakter dapat 
diintegrasikan melalui kegiatan belajar mengajar dan juga dalam sikap guru terhdap anak, sebab melalui proses pembelajaran ini lah guru dapat mengajarkan suatu pengorbanan.

c. Teman sebaya

Pada saat masa remaja karakter nya pun semakin kelihatan karena pengaruh dari teman sebaya nya. Dilihat dari psikologis anak, bahwa dimasa remaja merupakan masa-masa proses pencarian jati diri, sehingga remaja selalu tertarik dengan hal-hal yang baru dilihat nya. maka dari itu lah teman dalam hal sebaya yang hanya menemani virtual.

d. Lingkungan sekolah

Adanya lembaga pendidikan yaitu sekolah juga menjadi faktor dalam pengaruh pendidikan karakter pada anak. Suasana disekolah harus diatur dan ditata sesuai dengan nilai karakter yang akan ditanamkan pada diri anak. Oleh karena itu lah, sangat perlu adanya kerjasama antara seluruh pihak yang menyelenggarakan pendidikan karakater di lingkungan sekolah ini, guna bertujuan penanaman karakter terhadap anak secara nyata dan efektif.

e. Media

Pada masa sekarang ini teknologi sangat berkembang dengan pesat yang juga membawa pengaruh pada anak. Dalam hal media ini anak masih belum bisa menyaring atau memfilter apa saja yang telah ia lihat. jika melihat dengan mudahnya anak mengakses dan mengoperasikan gawai nya, maka tidak salah jika ia tidak dapat dikontrol dengan baik lagi dalam penggunaannya. Oleh karena itu, gawai menjadi pengaruh negative bagi anak karna fungsi dan tujuannya yang disalah gunakan sehingga menjadi perusak karakter remaja.

\section{B. Game online}

\section{Pengertian Game Online}

Menurut Mulyasanti (2012: 21) game online memiliki arti sebagai game atau permainan yang berhubungan dengan komputer yang dapat dimainkan oleh multiperan melalui saluran internet. Sedangkan menurut Jonathan (2015: 21) menyatakan bahwa game online merupakan sebagai satu diantara bentuk dari komunitas permainan digital yang sangat digemari dan perkembangan nya pun cukup pesat, serta sebagai sebuah 
fasilitas yang sedang menjamur, sekaligus juga sebagai game online untuk bermain maya yang mengagumkan para konsumen dengan memberikan tingkat kompetensi atau kemampuan interaksi sosial dan dorongan psikologis yang lebih luas.

Berdasarakan pernyataan diatas diambil keputusan, bahwa game online merupakan sebuah game atau permainan modern yang berbasis internet. Permainan ini pun dapat dikreasikan dengan melibatkan individu atau kelompok dan tidak lupa dengan aturan yang sudah berlaku. Game online juga merupakan permainan yang kekinian yang dapat dipakai pada media jasa internet yang memiliki tujuan tersendiri, yaitu sebagai hiburan terhadap individu sehingga ada nya menang dan kalah merupakan hal yang biasa.

\section{Faktor Pendorong Peserta Didik Bermain Game Online}

Ada 3 faktor pendorong peserta didik yang bermain game online (Cooper, 2009) diantaranya adalah sebagai berikut:

a) Nilai pengalaman

Nilai pengalaman merupakan menjadi pegangan dan pengkajian untuk seseorang yang tidak terlepas dari setiap kehidupan insan manusia. Nilai pengalaman sebagai penerimaan dari dunia, bentuknya pasif. Misalnya, menikmati dunia, menikmati konser musik, pemandangan dan lain sebagainya.

b) Interaksi sosial

Interaksi sosial yang terdapat pada game online bersifat umum yakni berarti tidak ada batasan, dan pemain game pun dapat membawa diri nya untuk dapat mengetahui atau mengelaborasi potensi diri. Jika peranan sosial atau kemasyarakatan dapat berlangsung dengan baik dan sedemikian mungkin, maka semua kalangan pemain game online dapat mengembangkan dirinya melalui berinteraksi antara sesama pemain game online lainnya tanpa mendebatkan suatu perbedaan, baik itu perbedaan ras, suku, etnis, budaya, atau pun agama. Interaksi sosial dapat berjalan dengan baik dengan ada nya suatu komunitas yang terdapat di dalam game online tersebut.

c) Gaya hidup

Gaya hidup merupakan suatu pola hidup dari individu yang ada di alam semesta ini yang diungkapkan dalam bentuk kegiatan, kecendrungan dan opini 
nya. Seseorang yang senang memainkan game online merupakan sebagai sebuah model dalam mengungkapkan sesuatu yang ia gemari atau juga dapat terjadi saat mereka merasa kecewa sehingga terjadi lah perilaku excapism.

3. Pengaruh game online terhadap karakter peserta didik

Menurut Akhmad Muhaimin (2011: 39) pada ketika bermain game sewaktu sekolah, orang tua pasti selalu membatasi agar dapat menyesuaikan waktu nya dalam bermain. Seperti yang kita ketahui bahwa anak-anak yang tidak mendapat teguran ia akan selalu melakukan hal tersebut, sekalipun itu salah. Hal yang menjadi kemarahan orang tua adalah pada saat penilaian akhir sekolah atau hasil akhir sekolah. Jika nilai pada rapor menurun, pasti nya orang tua akan menyalahkan anak nya yang berlebihan dalam bermain game. Tetapi, pada fakta nya pengaruh game bukan seburuk itu dalam hal pembelajaran atau terhadap perilaku atau pun karakter. Peserta didik yang biasanya sering dalam bermain game online justru ia lah yang mengantongi kemahiran dalam hal berinteraksi sosial dengan cukup baik, ia justru tau hal-hal mana yang baik dan buruk dalam berinteraksi dengan individu lainnya, sebagai contoh dalam sebua game online kita akan dipertemukan dengan player-player diberbagai daerah yang tentunya memiliki budaya yang berbeda-beda dan lain sebagai nya, dengan bermain game online didalam nya akan terjalin suatu interaksi sosial.

Remaja atau peserta didik merupakan usia yang rentan dalam hal ini. Mereka sangat menggemari game online tersebut. dengan kesuakaan remaja dalam bermain game maka remaja mempunyai tingkat konsentrasi lebih tinggi dari remaja lain yang artinya yang tidak sebanding dengan remaja lain, hal itu dapat dilihat dari mengenai apa saja yang telah berlangsung di sekitarnya. Setiap individu yang selalu bermain game online terdapat kepiawaian dalam mengendalikan sebagian kegiatan pada saat waktu yang beriringan, lazimnya disebut menjadi multitasking.

\section{SIMPULAN}

Berdasarkan pembahasan diatas, dapat disimpulkan dengan adanya pendidikan karakter sejauh ini masih sangat dibutuhkan terhadap segala aspek pendidikan. Guna keberlangsungan kehidupan yang lebih baik lagi. Pendidikan karakter sebagai suatu cara dalam memberikan arahan terhadap peserta didik supaya menjadikan individu yang benar-benar berkarakter. Pendidikan karakter yang berhubungan pada peserta didik yang candu bermain game dengan 
yang tidak candu, tentunya terdapat memiliki karakter yang berbeda antara individu satu dengan yang lainnya. Game online merupakan sebuah wadah bagi individu pada kegemarannya dalam bermain game yang melibatkan suatu individu dan kelompok dan ada aturan didalam nya. Pengaruh Game online tidak hanya dipandang sebagai negatif saja, tetapi juga memiliki dampak positif . berdasarkan pernyataan Suwarsi (2015: 89) bahwa game merupakan sebuah bagian untuk melatih hal-hal yang baik terhadap dunia nyata terhadap organisasi yang mengharapkan agar pemecahan masalah dilakukan dengan kerjasama. Kebisaan dalam berasumsi responsif yaitu karakter dunia masyarakat suatu bangsa yang menghormati multikulturalisme menjadi pendukung masyarakat demokratis (Abbas et al, 2018).

\section{DAFTAR PUSTAKA}

Anis, M. Z. A., \& Wiyanarti, E. HISTORICAL LEARNING THROUGH THE HOSTORICAL THINKING LEARNING MODEL (MPBH) BASED ON ISSUE CENTERED HISTORY BRINGS STUDENTS CAN THINK CRITICAL THINKING REALITY AND EXPECTATIONS. Jurnal Socius, 10(1), 1-11.

Arkani, H. (2017, December). Pembentukan kepribadian oleh guru melalui pendidikan karakter di sma puspita kabupaten banyuasin. In PROSIDING SEMINAR NASIONAL PROGRAM PASCASARJANA UNIVERSITAS PGRI PALEMBANG.

Budiman, H. (2017). Peran teknologi informasi dan komunikasi dalam pendidikan. AlTadzkiyyah: Jurnal Pendidikan Islam, 8(1), 31-43.

http://repository.usd.ac.id/36807/2/161114082_full.pdf

https://ulm.ac.id/id/2018/07/27/perkembangan-pendidikan-di-era-digital/

https://www.ruangguru.com/blog/pentingnya-pendidikan-karakter-untuk-anak

PENDIDIKAN KARAKTER S Sarbaini, EW ABBAS, W Wahyu, A SOFYAN Pendidikan Karakter 
Rahmah, R., Hasanah, M., \& Mutiani, M. (2021). The Integration of Local Content on Action Materials-Economic Principles Related to Human Needs. The Innovation of Social Studies Journal, 2(2), 143-150.

Syaharuddin, S., \& Mutiani, M. (2020). Strategi Pembelajaran IPS: Konsep dan Aplikasi. 